\title{
How the University Lost Its Way: Sixteen Threats to Academic Freedom
}

\section{Dennis Hayes ${ }^{1,2}$}

Published online: 27 November 2019

(C) Springer Nature Switzerland AG 2019

Are you happy to let someone tell you what to think? No one is. In universities, where academics have a particular role encapsulated in the phrase 'academic freedom'- the responsibility to speak your mind and challenge conventional wisdom - they have a duty to refuse to be told what to think. My challenge to academics at the Higher Education Institutional Research (HEIR) Conference 2019 was that, in their unquestioning compliance with many familiar functions of the university today, they have willingly accepted innovations and impositions that do just that, tell you what to think. It is time to give them a wake-up call.

Professor Cary Nelson, the then President of the American Association of University Professors (AAUP) ${ }^{1}$, in his book No University is an Island: Saving Academic Freedom (Nelson 2010: 53-60) lists sixteen threats to academic freedom to show how US campuses have lost their way. He notes at the end of his list that a decade earlier he would have collapsed many of them into 'corporatization' or as we might more pejoratively call it 'McDonaldization'. But many threats that may have their origins in the general and seemingly inevitable drift to McDonaldization have evolved and need to be treated separately. I would go further and say that many of the

${ }^{1}$ See https://www.aaup.org/.

Dennis Hayes

D.Hayes@derby.ac.uk

1 University of Derby, Derby, UK

2 Academics for Academic Freedom, Derby, UK 
developments undermining universities are cultural rather than a result of economic or faux economic factors. Here are my sixteen points for 2019. They show how UK campuses have also lost their way.

\section{'Therapy' or 'Victim' Culture}

What is the 'magic word' if you want something? ... No, it's not 'Please!'... It is 'I am offended!'.

What Julie Burchill calls 'cry bullying' is how you get your way in the twenty-first century. You present yourself as a victim. That puts you beyond all criticism. Over the last 30 years, therapy culture has come to dominate professional and academic life. The new form of professionalism is providing therapy to victims (T2V) (Ecclestone and Hayes 2009/2019).

There is no doubt that the dominant culture in universities is therapeutic. When writers like Greg Lukianoff, the president of the Foundation for Individual Rights in Education (FIRE) ${ }^{2}$, discuss the rise of censorship on campus, they often find the explanation in the therapeutic turn but they do not often develop their thoughts (Lukianoff 2014). In The Dangerous Rise of Therapeutic Education (2009/2019), Kathryn Ecclestone and I wrote a chapter using the term I coined, the 'therapeutic university', to encapsulate what was happening to universities. One of our critics said we were wrong about the university because its commitment to the pursuit of knowledge protected it from a narcissistic navel-gazing turn. Ten years on, the clamour about 'safe spaces' and 'trigger warnings' reveals how universities have been transformed. Students are now seen and see themselves as vulnerable. This vulnerability is embodied in the desire to never be offended but if you fear to offend you have no academic freedom.

\section{Prevent}

Many academics refuse to recognise internal cultural threats to academic freedom and prefer to focus on external threats such as the Prevent Duty.

The Prevent Duty is an obvious infringement of academic freedom by the state. It became law on 21 September 2015 as a result of the Counter-Terrorism and Security Act $2015^{3}$. One requirement of that duty is to vet external speakers. Vetting any speakers should be anathema to a university. All speakers should be allowed to speak and be challenged. The criticism of the duty by the National Union of Students (NUS) ${ }^{4}$ and the University and College Union $(\mathrm{UCU})^{5}$ ignores that fact that this legislation builds on their own practice of 'No Platforming' speakers they disagree with. But the fundamental problem

\footnotetext{
${ }^{2}$ See https://www.thefire.org/.

${ }^{3}$ See http://www.legislation.gov.uk/ukpga/2015/6/contents/enacted.

${ }^{4}$ See https://www.nus.org.uk/.

${ }^{5}$ See https://www.ucu.org.uk/. 
with the Prevent Duty is that it represents those in danger or radicalisation as vulnerable young people rather than alienated youth. Although it is an intrusion by the state, it taps into the therapeutic culture that exists in universities.

\section{Instrumentalism}

Instrumentalism is so much part of our thinking that we forget that the university's purpose is the pursuit of knowledge without fear or favour. Once its aim is something else, whether that is social mobility, employability, building a sustainable future, or revitalising the economy, academic freedom will be narrowed. Teaching and research linked to stated outcomes removes academic freedom.

\section{Groupthink}

Groupthink is rife in the universities. Many academics are left wing according to Noah Carl in his report for the Adam Smith Institute (Carl 2017). We know that 9 out of 10 academics are remainers, who voted to stay in the European Union in the 2016 referendum. Brexiters, whether staff or students, keep a low profile. Groupthink is strong in many of the disciplines but here, I will keep to my own, education. Education is often subordinated to achieving social justice, rather than education. Education departments would be unlikely to employ someone who believed in a knowledgebased curriculum. They prefer someone who is committed to a New Labour project like 'inclusion'. And we know that if you disagree with inclusion, you are mentally ill, at least according to one of my former colleagues who claims that 'inclusion phobia' constitutes a psychiatric thought disorder (Robinson and Goodey 2017).

\section{REF/TEF/KEF ${ }^{6}$}

Professor Derek Sayer, author of Rank Hypocrisies: the Insult of the REF (Sayer 2015a), noted that the estimated cost of the Research Excellence Framework (REF) was $£ 250$ million ( $£ 41$ m p.a.), but a more realistic estimate is $£ 1$ bn which covers time spent on the REF at individual universities that was not costed. He concludes that that 'Staff time was... overwhelmingly the most significant submission cost for HEIs' (Sayer 2015b).

The real criticism of the REF is that it wastes our time and for this reason is an attack on our academic freedom. It also encourages mediocrity with publications churned out for publications sake.

As Anthony Stanonis, from Queen's University Belfast, rightly notes, really important research takes time whereas the REF encourages a short-term view of research (Stanonis 2016). The REF industry has stolen our time and left us too busy to have

\footnotetext{
${ }^{6}$ Research Excellence Framework (REF), Teaching Excellence and Student Outcomes Framework (TEF) and Knowledge Exchange Framework (KEF) are policy measures developed for assessment of various aspects of research excellence in UK higher education.
} 
academic freedom. The same is true, mutatis mutandis, for the Teaching Excellence Framework (TEF) and the Knowledge Exchange Framework (KEF).

\section{Authoritarian Bureaucracies}

We may all have experience of authoritarian, inflexible, demanding, and bullying managers. But we recognise them for what they are. We forget that the procedures and practices of committees in the university bureaucracy are hardly vehicles for free speech. Their power structures and procedures rarely allow debate and speaking up is frowned upon. Why do we have so many committees and managers? The answer is that managing is easier than thinking, teaching, and research. Nor are the Human Resource (HR) departments the friends of academic freedom. They force academics to adopt management speak to describe their work and impose suspect but fashionable political training upon us, most recently their growing concern with 'unconscious bias' and the victim fest that 'intersectionality' has become. Academics For Academic Freedom $(\mathrm{AFAF})^{7}$, like other international campaign groups, opposes mandatory training about contested issues. Almost everyone I know just goes along with management of HRimposed training. Where does this leave them as academics?

\section{Marketisation}

The idea that universities are businesses is something that university managers get excited about. It is an ideological joy to think you are a business like Amazon. I am surprised no Vice-Chancellor (VC) has yet renamed a main hall as a 'fulfilment centre'.

It is a common criticism of marketization that universities are not businesses but are a public good. Fair enough, but what damage does thinking you are 'business-like' - to use a term borrowed from the research of my colleague Dr Kuldeep Banwait (2018) — do to academic freedom? It changes it fundamentally. As one VC argued in a debate, 'The time for semantic debate is over students are customers'. But students can never be customers because education is not the sort of product you order. The reason is simple. Students do not know how education will change them. They cannot know what they are buying. Accepting the idea that students can act like customers means that they will attempt to tell you what they deserve and academic criticism is not what they want. But the job of the academic is criticism. It is hard to oppose this 'student as customer' ideology as its everywhere but it is incoherent, totally incoherent. The more academics adapt to the demands of students the less academic freedom they have.

\footnotetext{
$\overline{{ }^{7} \text { See https://www.afaf.org.uk/about/. }}$
} 


\section{Financial Crises}

Universities claim to be short of money but have lots to spend on non-academic posts and the many often therapeutic activities that constitute the 'student experience'. I will say nothing about VC salaries. Many academics sit in pointless meetings without ever considering how much they cost - consider the REF costs discussed earlier-now consider the cost of the bureaucratic superstructure of universities. Staffing is one example. The basic figures are informative. Forty-nine percent of university employees are on academic contacts (HESA 2018) but only 27 percent of these academics teach. Universities cry poverty and cut the time academics have to think by wasting their time in meetings. Claiming financial hardship is a selectively focused activity and one that does not support academic freedom.

\section{Advance HE}

Ever since, the Dearing Report (National Committee of Inquiry into Higher Education 1997), moves have been made to train the academic workforce, although there was never any evidence that teaching was bad. The history of the Institute for Learning and Teaching in Higher Education (ILT) ${ }^{8}$, the Higher Education Academy (HEA) ${ }^{9}$, and now Advance $\mathrm{HE}^{10}$ has not been a happy one. Changing from a potential professional body to a management project, it has lost its way. Gaining teaching qualifications takes time - a colleague has just become an HEA Fellow at the third time of trying. But it is more about forcing you to reflect in certain ways about your teaching and to ensure your work is 'evidence-based' but that is a highly selective base. The best 'evidence' if we have, if we need it, is just ignored (see Arum and Roksa 2011). At its heart, Advance HE is an attack on the autonomy of the academic. It is an attack on academic freedom.

\section{Gagging Orders}

Gagging orders have been in the news about sexual harassment cases but they are routine. AFAF has worked to defend many academics who were disciplined for what they said but cannot name them or talk about their cases. Gagging orders cover up the extent of attacks on academic freedom by universities. There are obviously many more cases that AFAF know of. This is the theme of the book by Alan Kors and Harvey Silverglate The Shadow University: The Betrayal of Liberty on America's Campuses (Kors and Silverglate 1998). Rarely does an academic risk break such an order to defend academic freedom.

\footnotetext{
${ }^{8}$ See https://www.northampton.ac.uk/research/research-institutes/the-institute-of-learning-and-teaching-inhigher-education-ilt/.

${ }^{9}$ See https://www.heacademy.ac.uk/.

${ }^{10} \mathrm{See}$ https://www.advance-he.ac.uk/.
} 


\section{Students}

Student Unions (SUs) are fond of 'No Platforming' speakers and banning newspapers, songs, and fancy dress. All this is well known and well publicised in the media and documented in the Free Speech University Rankings (FSUR) produced by the online magazine Spiked ${ }^{11}$. But student union officers constitute a more direct assault on academic freedom now that they are being incorporated into university management. Though they have formal independence, they are, in reality, part of management. They can now influence what is taught and how it is taught based mostly on fashionable ideas. SUs pose a serious threat to academic freedom.

This is exacerbated by the obsession with the 'student experience' which ignores the 'academic experience' which is what students should really get from being at university. Celebrating the student experience is a move away from academic life and is therefore a threat to academic freedom.

\section{University and College Union}

The American Association of University Professors (AAUP) has always put academic freedom at the forefront of its activities since it was founded in 1915-one of the founders was John Dewey whose thinking influences much of what now goes on in colleges and universities. The AAUP issued its Declaration of Principles on Academic Freedom and Academic Tenure in 1915, revised in 1940 and 1970 (see American Association of University Professors 2019). It influenced the thinking on Academic Freedom internationally.

UCU's statement of Academic Freedom was published in 2009 as a result of the creation of AFAF and a series of high-profile academic freedom cases. However, it has many caveats about the 'the responsibility to respect the democratic rights and freedoms of others' (UCU 2009). It is an empty statement because, in practice, UCU is partial in its defence of academic freedom and is more likely to call for the no platforming of speakers its activists dislike than defending the right of those they disagree with to speak.

\section{National Student Survey ${ }^{12}$}

Go down a few percentage points in the ridiculous 'How do you feel?' survey that is the UK's National Student Survey (NSS) and academics will be told to produce action plans to appease your students. If keeping students happy becomes the aim of management, then you are in the therapeutic university and your academic freedom has gone.

\footnotetext{
${ }^{11}$ See https://www.spiked-online.com/free-speech-university-rankings.

${ }^{12}$ See https://www.thestudentsurvey.com. 


\section{Parents}

Since when did we do parents? Parents now intervene in university life from the interview to the final thesis. They see university as a 'big school' and feel they are able to comment on teaching and course content. If universities treat students vulnerable, the influence of parents will increase and academic freedom will be constantly challenged. Parents are well versed in the 'safeguarding' obsession of schools and forget that their children are no longer children. They are adults.

\section{Academic Mobbing}

AFAF has a web page called The Banned List (Academics For Academic Freedom 2019) which contains a growing list of academics who have been the victims of attempts to stop them speaking. Increasingly, this takes the form of open letters and petitions calling for individuals to be sacked. Recent examples are groups of feminists denounced for wanting to discuss trans issues and considered to be Trans Exclusionary Radical Feminists (TERFs) and individuals who have views academics despise on homosexuality, or whose research is said to be ethically suspect. Academic mobbing is a dangerous development which not only threatens academic freedom but also academic livelihoods.

\section{Academics}

In 2009, Steve Fuller sketched some ideas towards a deep history of academic freedom focusing on its 'turbulent German history'. He is unequivocal that 'it was never assumed that academics themselves were its most reliable guardians' (Fuller 2009: 173). What can we say about academics today? Are they reliable guardians of academic freedom or have they become its enemies through cowardice and passivity, or because they are in denial and believe there is nothing to worry about? Do they believe academic freedom is alive and well in UK universities? Well, do you?

\section{References}

Academics For Academic Freedom (2019). The banned list. Academics for academic freedom. https://www. afaf.org.uk/the-banned-list/. Accessed 20 September 2019.

American Association of University Professors (2019). AAUP Principles. http://www.aaup-ui. org/Documents/Principles/index.html. Accessed 23 September 2019.

Arum, R., \& Roksa, J. (2011). Academically adrift: limited learning on college campuses. Chicago, Il: The University of Chicago Press.

Banwait, K. (2018). The student as customer: a study of the intensified marketisation of higher education in England. Unpublished EdD Thesis. Derby, UK: University of Derby: https://derby.openrepository. com/handle/10545/622828. Accessed 20 September 2019.

Carl, N. (2017). Lackademia: Why do academics lean left? London: Adam Smith Institute.

Ecclestone, K., \& Hayes, D. (2009/2019). The Dangerous Rise of Therapeutic Education (Second ed.). London and New York: Routledge. 
Fuller, S. (2009). The genealogy of judgement: towards a deep history of academic freedom. British Journal of Educational Studies, 57(2), 164-177. https://doi.org/10.1111/j.1467-8527.2009.00434.x.

HESA (2018). Higher education staff statistics: UK, 2016/17. 18 January. https://www.hesa.ac.uk/news/18-012018/sfr248-higher-education-staff-statistics. Accessed 20 September 2019.

Kors, A. C., \& Silverglate, H. A. (1998). The shadow university: the betrayal of liberty on America's campuses. New York, NY: The Free Press.

Lukianoff, G. (2014). Freedom from speech. New York, NY: Encounter books.

National Committee of Inquiry into Higher Education (1997). Higher education in the learning society. London: Her Majesty's Stationery Office. http://www.educationengland.org.uk/documents/dearing1997 /dearing1997.html. Accessed 23 September 2019.

Nelson, C. (2010). No university is an island: saving academic freedom. New York NY and London, UK: New York University Press.

Robinson, D., \& Goodey, C. (2017). Agency in the darkness: 'fear of the unknown', learning disability and teacher education for inclusion. International Journal of Inclusive Education, 22(4), 426-440. https://doi. org/10.1080/13603116.2017.1370738.

Sayer, D. (2015a). Rank hypocrisies: the insult of the REF. Thousand Oaks, CA and London, UK: Sage.

Sayer, D. (2015b). Why did the REF 2014 cost three times as much as the 2008 RAE? LSE Impact Blog, 8 March. https://blogs.lse.ac.uk/impactofsocialsciences/2015/08/03/why-did-the-2014-ref-cost-three-timesas-much-as-the-2008-rae-hint-its-not-just-because-of-impact/. Accessed 16 August 2019.

Stanonis, A. (2016). No time for muses: the research excellence framework and the pursuit of mediocrity. In C. Hudson \& J. Williams (Eds.), Why academic freedom matters: a response to current challenges (pp. 128144). London: Civitas.

UCU (2009). Statement on academic freedom. https:/www.ucu.org.uk/academicfreedom. Accessed 6 September 2019. 